Research Article

\title{
Planning for Small-Scale Business (USK) Batik Wastewater Treatment Plant X Yogyakarta
}

\author{
Intan Rahmalia" ${ }^{1 *}$, Farhan Muhammad Hilmi', Iva Yenis Septiariva ${ }^{2}$, Reifaldy \\ Tsany Betta Aryanto', Sri Dewi Handayani', Yesaya Emeraldy Priutama', \\ Ariyanti Sarwono', I Wayan Koko Suryawan'
}

${ }^{1}$ Faculty of Infrastructure Planning, Department of Environmental Engineering, Universitas Pertamina, Komplek Universitas Pertamina, DKI Jakarta, Jakarta Selatan, Indonesia

${ }^{2}$ Study Program of Civil Engineering, Faculty of Engineering, Universitas Sebelas Maret, Jalan Ir Sutami 36A Surakarta, Jawa Tengah 57126, Indonesia

${ }^{*}$ Corresponding author, e-mail: iwayankokosuryawanı@gmail.com

\section{(i) (2)}

\section{Abstract}

Small scale business / Usaha Skala Kecil (USK) X currently does not have a batik wastewater treatment unit. This condition causes the possibility of contamination to water bodies. USK X wastewater treatment applications' planning needs to be carried out sustainably, namely by reusing water. The process units needed in this planning are the sequencing batch reactor (SBR) and constructed wetlands. The effluent of textile wastewater with this system for parameters BOD, COD, TSS, sulfide, total oil \& fat, and color were $0.13 \mathrm{mg} / \mathrm{L} ; 106.5 \mathrm{mg} / \mathrm{L} ; 2.4 \mathrm{mg} / \mathrm{L} ; 0.036 \mathrm{mg} / \mathrm{L} ; 0.07 \mathrm{mg} / \mathrm{L}$; and 90.67 PtCo, respectively. The dimensions of the SBR unit required are 0.75 x 0.6 x $1 \mathrm{~m}$. Modification of the SBR unit uses an ozone generator to produce ozone gas which functions as oxidation of organic pollutants and colors in batik waste. After processing in the SBR unit, it is carried out using a constructed wetland with $2.56 \mathrm{~m}^{2}$.

Keywords: Batik wastewater; constructed wetland; sequencing batch reactor (SBR); textile

\section{Introduction}

Batik is one of the ancestral heritage and also as a cultural wealth of Indonesia. Batik production in various cities in Indonesia continues to increase as one of the responses to the inauguration of batik as an original Indonesian cultural work on October 2, 2009 by the United Nations Educational, Scientific, and Cultural Organization (UNESCO). Along with the development and great public interest in batik, batik has been recognized by the domestic and international community. Now batik is produced as a cultural and industrial product made from small to large scale (Indrayani, 2018). However, increased consumer response to batik is not accompanied by an understanding of batik craftsmen regarding the impact of waste on the environment (Sari et al., 2015). In the batik production process, the main natural resource used is water. The large water usage debits produce large quantities of liquid waste. It is estimated that water use in the batik-making process is approximately $25-50 \mathrm{~m}^{2}$ per meter of batik cloth (Indrayani, 2018). The annual supply of water for the batik industry is equivalent to the supply of clean water for 2,50o households (Balai Besar Crafts and Batik, 2010).

The batik industry wastewater contains high Biological Oxygen Demand (BOD), Chemical Oxygen Demand (COD), pH, temperature, Total Suspended Solid (TSS), and Total Dissolved Solid 
(TDS). It has the potential to pollute the environment, especially water bodies (Indrayani et al., 2018). High temperatures will also cause the dissolved oxygen content in the water to decrease, which will kill organisms. Organic waste will increase nitrogen levels into nitrate compounds which cause a foul odour (Sastrawijaya, 1991). Therefore, it is necessary to treat liquid waste in the batik industry before finally being discharged into water bodies or reused. The reuse of water by the textile industry is very beneficial to the economy, reducing the use of clean water in the dyeing process and increasing environmental aesthetics (Septiariva et al., 2021). Nutrient content in textile wastewater can also have an impact on the impact of eutrophication. Nutrient nitrogen and phosphate are environmental pollution factors commonly found in water bodies (Fadhilah et al., 2020). Research says that there has been pollution of several rivers in Yogyakarta, such as the Code River (Marlina et al., 2020), the Gajahwong River (Djumanto et al., 2013), the Tepus River, and the Ngemplak River (Sutardi et al., 2017).

Based on the background described previously, a Wastewater Treatment Plant (WWTP) for the batik industry needs to be built at USK Batik X, Yogyakarta, to reduce the burden of pollutants entering the river in Yogyakarta. This WWTP will accommodate 1 production house. The WWTP that was built puts forward the concept of aesthetics where the WWTP land is also made a garden to eliminate the community paradigm that WWTP is a slum place. The results of the application of the appropriate technology design, it is hoped that the USK Batik X, Yogyakarta, can become a center for USK batik that have a production process that is environmentally sustainable and at the same time has an affordable business advantage. The city of Yogyakarta is known as the "Batik City" because the majority of its population earn their livelihood by establishing a batik business. However, there are quite a lot of batik IKM (Small and Medium Industries) centers in the city of Yogyakarta that do not have processing for the batik waste produced. On the other hand, the density of the city of Yogyakarta causes at least the available land to construct a building, while the batik waste requires further processing. Therefore, a communal batik waste management system is needed (which comes with the required costs), that management is effective and efficient.

The planning of the WWTP for the batik industry aims to be the basis for the presentation of the WWTP design innovation competition. In this batik industry WWTP planning report, the aim is to determine and find innovations in batik industry wastewater treatment, determine effective units to handle batik industry wastewater following PerMenLH standards no. 5 of 2014 concerning Wastewater Quality Standards, and design batik industry wastewater treatment plants with good environmental management.

\section{Methods}

There are several stages in the process of making batik in the written batik industry. The process can be divided into traditional techniques and fabrication processes using modern technology. Overall, making batik cloth consists of pre-treatment, waxing, coloring, washing, and drying. The dyeing batik industry produces liquid waste from the batik production process, which contains artificial and natural substances. The substances contained in it vary widely, including residual wax, natural dyes, solvents, salts, fixators, and so on. The dyes commonly used in the batik industry are synthetic dyes (naphthol and indigo sol dyes) and natural dyes. Therefore, it is necessary to treat this type of wastewater not to cause environmental pollution to become more complicated. Wastewater is generally defined as residual water from an activity that is no longer used, but further processing is needed to ensure that the batik liquid waste is safe to be discharged into the environment. Liquid waste generated from batik production activities has the characteristics of having a cloudy color, foaming, high $\mathrm{pH}$, high concentrations of BOD and COD, and containing oil and fat.

This study was collected through literature from the batik-making process along with the wastewater quality standards used. The planning used in this research is an integration of physical, chemical and biological processing. That is by a combination of planning with the calculation of pretreatment of ozone and ending with post-treatment with wetland technology. 
Overall, the secondary data that we take are the results of direct observations at the case study locations, both through staff interviews and testing the characteristics of wastewater. Wastewater testing or the pre-preliminary test of wastewater characteristics is carried out through composite sampling. The samples are collected by mixing several models produced by wastewater in each process using grab sampling, representing the wastewater characteristics in each batik production process.

Table 1. Characteristics of batik wastewater

\begin{tabular}{|c|c|c|c|c|}
\hline No & Parameters & Unit & Value ${ }^{*}$ & Standard $\left.{ }^{* *}\right)$ \\
\hline 1. & $\mathrm{pH}$ & - & $7 \cdot 4$ & $6.0-9.0$ \\
\hline 2. & Temperature & C & 30.1 & \pm 3 of air temperature \\
\hline 3. & BOD & $\mathrm{mg} / \mathrm{L}$ & $2.170,0$ & 85 \\
\hline 4. & COD & $\mathrm{mg} / \mathrm{L}$ & $8.817,5$ & 250 \\
\hline 5 & $\mathrm{BOD} / \mathrm{COD}$ & - & & - \\
\hline 5. & TSS & $\mathrm{mg} / \mathrm{L}$ & 1.825 & 60 \\
\hline 6. & TDS & $\mathrm{mg} / \mathrm{L}$ & 683 & 2000 \\
\hline 7. & Phenol & $\mathrm{mg} / \mathrm{L}$ & 0.245 & 0.5 \\
\hline 8. & Total Chrome & $\mathrm{mg} / \mathrm{L}$ & $<0.0363$ & 1 \\
\hline 9 . & Total Ammonia $\left(\mathrm{NH}_{3}-\mathrm{N}\right)$ & $\mathrm{mg} / \mathrm{L}$ & 0.2763 & 3 \\
\hline 10. & Sulfide (S) & $\mathrm{mg} / \mathrm{L}$ & 0.6618 & 0.3 \\
\hline 11. & Total Oils \& Fats & $\mathrm{mg} / \mathrm{L}$ & 10 & 0.5 \\
\hline 12. & Turbidity & NTU & 89.76 & - \\
\hline 13. & Color & PtCo & 692.2 & $200^{* * *}$ \\
\hline
\end{tabular}

* Results of Wastewater Test Results of Batik Fabric Production.

** DIY Regional Regulation Number 7 of 2016 concerning wastewater quality standards for the batik industry.

*** Regulation of the Minister of Environment and Forestry of the Republic of Indonesia Number P.16/MENLHK/SETJEN/KUM.1/4/2019.

\section{Result and Discussion}

The wastewater treatment unit used is a sequenced batch reactor and a constructed wetland in the WWTP planning process. The following is a flow chart image along with an explanation. In the planning design for wastewater treatment, the results of batik production activities consist of two main components in the treatment unit, namely Sequencing Batch Reactor (SBR) and Sub-Surface Wetland. BOD and Total Oil and Fat content are removed in the SBR unit in the designed WWTP installation. In general, the SBR process uses a fill-and-draw reactor with a complete mixing process that occurs during the reaction stage (aeration) in the bath (after the filling process). It is followed by a clarification process that takes place in the same tank. All SBR systems have five sequential stages, which are carried out as follows, namely, fill, react (aeration), settle (sedimentation/clarification), draw (decant), and idle (Metcalf \& Eddy, 2014).

The selection of the SBR unit as a batik wastewater treatment unit is considered based on several aspects, including the advantages and disadvantages of the process. The following illustrates the advantages and disadvantages of the SBR unit, which is the background for selecting this unit as a batik wastewater treatment medium. Operation on this unit is usually based on long HRT and SRT values. The process on this unit is quite attractive to a small community due to its simplicity of operation and relatively low cost. And SBR is a simplified process where clarifier and RAS pumping are not required. However, in the WWTP design, which specified its use for batik industrial wastewater treatment, several process modifications were applied to meet the standard quality criteria to be achieved and adapted to the characteristics of the liquid waste influent. Improvements were carried out during aeration, where oxygen as an oxidizing energy source was substituted with ozone. The use of ozone is used to remove organic content while reducing colour and odour levels. In addition, to increase the efficiency of oil and fat emulsion removal, a coalescer pack or oil trap plate is used, which can then be removed to the surface by a skimmer in the form of a belt conveyor. Based on the results of design 
considerations carried out, the batik wastewater treatment process scheme in the SBR unit is obtained, which is described in Table 2.

Table 2. Planning flow of sbr unit wastewater treatment process

\begin{tabular}{|c|c|c|c|c|}
\hline No. & Volume & Cycle Time & Process & Operation \\
\hline 1 & $1 \mathrm{~m}^{3}$ & $12 \mathrm{~h}$ & Fill & $\begin{array}{l}\text { Ozon (off) } \\
\text { Skimmer (on) }\end{array}$ \\
\hline 2 & $1 \mathrm{~m}^{3}$ & $8 \mathrm{~h}$ & React & $\begin{array}{l}\text { Ozon (on) } \\
\text { Skimmer (off) }\end{array}$ \\
\hline 3 & $1 \mathrm{~m}^{3}$ & $2 \mathrm{~h}$ & Settle & $\begin{array}{l}\text { Ozon (off) } \\
\text { Skimmer (on) }\end{array}$ \\
\hline 4 & $1 \mathrm{~m}^{3}$ & $2 \mathrm{~h}$ & Draw & $\begin{array}{l}\text { Ozon (off) } \\
\text { Skimmer (off) }\end{array}$ \\
\hline 5 & - & $\mathrm{oh}$ & Idle & $\begin{array}{l}\text { Ozon (off) } \\
\text { Skimmer (off) }\end{array}$ \\
\hline
\end{tabular}

In designing the SBR unit for batik wastewater treatment, several physical modifications of the unit were applied. Regardless of the consideration of the characteristics of the influent waste, which has a fairly small discharge and a discontinuous flow (plug flow for one cycle batch), which is $624 \mathrm{~L} /$ week or $0.089 \mathrm{~m}^{3} /$ day, and the production of batik cloth is not large for a week, which is 30 fabrics. That in this case, the input and output of materials that are accommodated in wastewater are quantified in insignificant quantities to require large-scale treatment processes. The mechanical equipment used in the aeration stage of the bubble diffuser is directly connected to the ozone generator. Ozone $\left(\mathrm{O}_{3}\right)$ acts as an energy source for oxidizing organic constituents in batik wastewater. This treatment stage is referred to as pre-ozonation, which refers to the addition of ozone into wastewater before coagulation, which oxidizes the content of coloured substances that form organic compounds and other oxidizable constituents in wastewater. And the use of a diffuser as an ozone transfer medium in wastewater can be following the purpose of wastewater treatment using ozone for oxidation besides, the transfer efficiency of this device is above $90 \%$ (Greg et al., 2011)

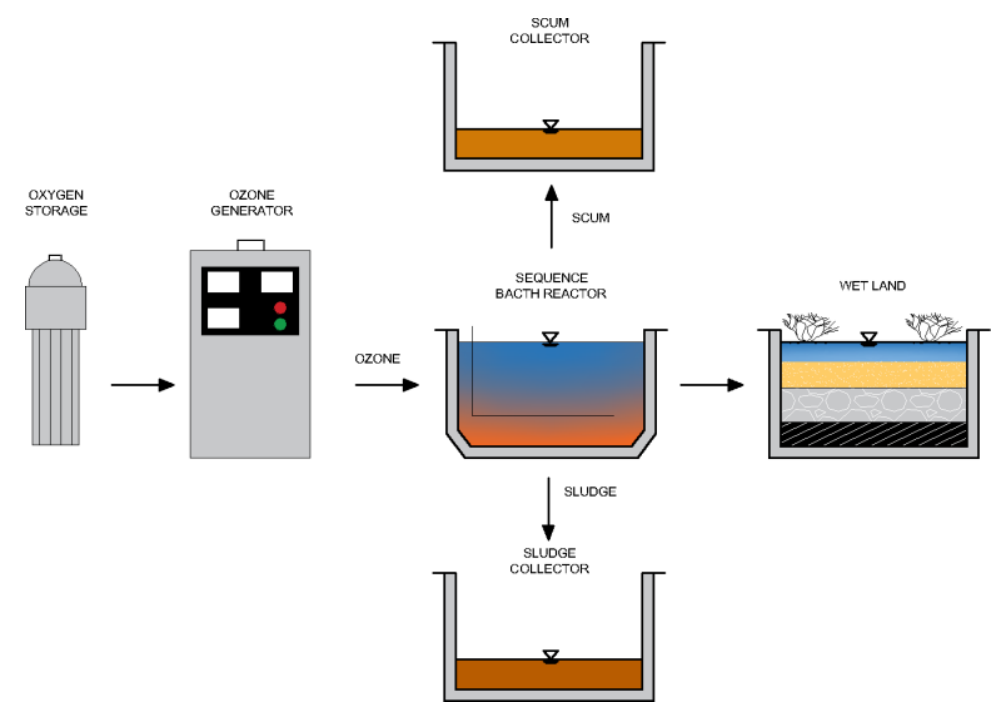

Figure 1. Flowchart of batik WWTP for small-scale business (USK) batik in Yogyakarta 
The use of wax which dominates the process, makes the wastewater produced from batik cloth work contain a lot of oil and fat, mainly from soaking activities to release wax. This makes the process of removing oil and fat content an important process in batik wastewater treatment. The oil and grease removal process is the initial stage of processing in the SBR unit, supported by a Coalescer Pack to help increase the percentage of processing removal. Thus, to solve the presence of emulsions in wastewater, Coalescer media is considered an appropriate solution. The principle applied in this tool is that fine droplets hitting the walls of the Coalescer media will form droplets of larger diameter downstream of the media because over time. Smaller droplet aggregates and larger droplets are more likely to be joined (or fused) with separate layers so that the droplets are no longer considered entrained. Therefore, when released from the coalescer medium, larger diameter droplets will have greater buoyancy to be removed in the air and water level. Traditionally, gravity separators were used to treat emulsions before the use of Coalescer media. However, to settle the fine droplets (emulsion) and ensure laminar flow in the gravity separator unit, large bath sizes and long residence times are required to support this process. It can take five, ten, and or even thirty minutes to make the separation, depending on the physical properties of the flow.

Oil skimming is the process of removing oil from the surface of the water mixed with oil. Several oil filtration devices and technologies depend on the type, the scope of the challenge, and the application. From these considerations, it can be judged that the device is more effective or efficient than the others. In this design, we use a belt conveyor to separate the oil on the water surface. The technology was chosen because the maintenance and operation of the tool make it easy for users even with significant capital investment. In addition, the lifted oil will be automatically transferred to the oil collection tank to be directly used for other purposes (can be sold to fuel producers or other manufacturers).

The cycle that occurs in the SBR processing consists of 1 cycle (fill-react-draw-idle) for 24 hours. The functional design of the SBR unit is shown in table 1.5. In creating this SBR unit, several processing stages, starting from primary treatment to secondary treatment, can occur in one unit. With the presence of ozone as a substitute for the use of oxygen, it can increase the level of processing steps to become a tertiary treatment that is functionally to eliminate odours and tastes so that the expected effluent from the SBR processing process is of sufficient quality to be distributed to the environment. However, further processing is applied because this unit's allowance is insufficient to meet the acceptable quality standards.

Constructed wetland is one of the process units in the WWTP system used to reduce the concentration of pollutants in wastewater. In the design of the WWTP system, the Batik UKM Constructed Wetland is used as a follow-up treatment after the SBR unit. This processing unit is used to set aside BOD, COD, TSS, Sulfide, and color parameters. This unit effectively removes organic material and dissolved substances in wastewater processed by vegetation by biochemical processes. Plants generally used in the wetland process unit are non-consumable plants because plants will absorb dissolved substances in wastewater that are highly toxic if they accumulate continuously. Thus, vegetation waste will be more when using consumption crops such as fruit, and it won't be easy to process. Vegetation in SSF is planted on sand or gravel media. Plants above can absorb oxygen using the leaves and stems, and then oxygen is transferred to the roots so that the conditions around the roots become aerobic. Plants can transfer about $5-45 \mathrm{mg} \mathrm{O} / \mathrm{day} / \mathrm{m}^{2}$ (Khiatuddin, 2010). To increase the efficiency of the SSF unit, extensive root contact with water is needed, so that root penetration into the media needs to be considered. The advantage of the SSF system is that it does not produce odours because the process in the unit is aerobic. In addition, SSF does not become a breeding ground for mosquitoes or insects that can cause disease. While the drawback of this SSF system is that it is easier to blockage because bacteria in the media will produce biofilm mucus that can clog the space between the media, it is necessary to clean the media with clean water at least 2 times a year. In addition, to overcome blockages, an inlet tub can be made as a large TSS filter so that it does not directly enter the SSF unit. 
Based on data from Metcalf \& Eddy and Mitchell et al., they obtained percent removal of biological and chemical constituents in wastewater in the treatment process using SBR and Sub-Surface Wetland (SSF-Wetland) units (Metcalf \& Eddy, 2014; Mitchell et al., 1998). Table 3 shows the percentage of removal and the estimated effluent yield for each processing process, along with the number of constituents removed.

Table 3. Percentage of provision for pollutants in WWTP batik

\begin{tabular}{|c|c|c|c|c|c|c|}
\hline \multirow[t]{2}{*}{ Parameters } & \multirow[t]{2}{*}{$\begin{array}{l}\text { Influent } \\
(\mathrm{mg} / \mathrm{L})\end{array}$} & \multicolumn{2}{|c|}{$\begin{array}{l}\text { Sequencing Batch } \\
\text { Reactor }\end{array}$} & \multicolumn{2}{|c|}{ SSF Wetland } & \multirow[t]{2}{*}{$\begin{array}{l}\text { Standard } \\
(\mathrm{mg} / \mathrm{L})\end{array}$} \\
\hline & & $\begin{array}{l}\% \\
\text { Removal }\end{array}$ & $\begin{array}{l}\text { Effluent } \\
\text { Process }\end{array}$ & $\begin{array}{l}\% \\
\text { Removal }\end{array}$ & $\begin{array}{l}\text { Effluent } \\
\text { Process }\end{array}$ & \\
\hline $\mathrm{BOD}$ & 2170 & $90 \%$ & 217 & $99.94 \%$ & 0.13 & 85 \\
\hline COD & 8154 & $90 \%$ & 815.4 & $87 \%$ & 106.5 & 250 \\
\hline TSS & 756 & $97 \%$ & 23 & $89.43 \%$ & 2.40 & 60 \\
\hline Sulfide & 0.6618 & o & 0.66 & $94.56 \%$ & 0.036 & 0.3 \\
\hline Oil \& Fat & 10 & $99.25 \%$ & 0.07 & o\% & 0.07 & 0.5 \\
\hline Total & 692.2 & $86.9 \%^{1}$ & 90.67 & - & - & 200 \\
\hline
\end{tabular}

${ }^{1}$ (Suryawan et al., 2019)

SBR removes organic matter, suspended solids, and oils and fats. Table 4 is the design criteria used as a reference for the design of the SBR unit for batik wastewater treatment. Details of the design of the SBR unit can be seen in Table 5 and Table 6. The design specifications for the ozone generator in the method of batik wastewater treatment in the SBR unit can be seen in Table 7. Liquid-Liquid Coalescers are used to accelerate the incorporation of many droplets to form a lower number of droplets. , but with a larger diameter. In general, when two liquids are insoluble or insoluble in each other, they can form a colloidal emulsion or suspension, for example, oil and water. The finer droplets dispersed in the emulsion have more stable properties. This is because the magnitude of the buoyancy strength decreases as the droplet diameter decreases (ACS, 2012).

Table 4. Typical design criteria for sbr units

\begin{tabular}{lll}
\hline Parameter & Unit & Nilai \\
\hline SRT (Sludge Age) & day & $15-30$ \\
F/M & $\mathrm{kg} \mathrm{BOD/kg} \mathrm{MLVSS.day}$ & $0.004-0.1$ \\
Volumetric Loading & $\mathrm{kg} \mathrm{BOD/day}$ & $0.1-0.3$ \\
MLSS & $\mathrm{mg} / \mathrm{L}$ & $2000-5000$ \\
Total HRT & hours & $15-40$ \\
Charging Time & hours & 3 \\
Aeration Time & hours & 2 \\
Deposition Time & hours & 0.5 \\
Supernatant Precipitation Time & hours & 0.5 \\
\hline
\end{tabular}

(Metcalf \& Eddy, 2014)

The SBR unit is designed to eliminate primary and secondary stages in typical WWTPs, reducing operational and maintenance requirements. In conventional biological nutrient removal systems, anoxic tanks, anoxic stirring tanks, toxic tanks, aeration and recirculation pumps are required. With SBR, all these units can be filled in one tank/reactor using aeration or stirring equipment. This, of course, can minimize the need for operation and maintenance. Since the core of the SBR system is control, automatic valves, and automatic switches, it requires more maintenance than conventional activated sludge systems. The SBR used to treat USK Batik X wastewater is small, so it is not too difficult to maintain SBR. 
able 5. Initial data for calculation of batch sbr unit

\begin{tabular}{lll}
\hline Parameters & Unit & Value \\
\hline Q (wastewater discharge) & liter/week & 624 \\
Full water depth $\left(\mathrm{h}_{\text {full }}\right)$ & $\mathrm{m}$ & 1 \\
Decant depth $\left(\mathrm{h}_{\text {decant }}\right)$ & $\mathrm{m}$ & 0.2 \\
BOD Concentration $(\mathrm{So})$ & $\mathrm{mg} / \mathrm{L}$ & 2170 \\
COD concentration & $\mathrm{mg} / \mathrm{L}$ & 8817.5 \\
Total Ammonia Concentration $\left(\mathrm{NH}_{3}-\mathrm{N}\right)$ & $\mathrm{mg} / \mathrm{L}$ & 0.2763 \\
MLSS concentration & $\mathrm{mg} / \mathrm{L}$ & 3250 \\
SVI & $\mathrm{mg} / \mathrm{L}$ & 120 \\
Fill/Decant & - & 0.33 \\
bsCOD & $\mathrm{mg} / \mathrm{L}$ & 2083.2 \\
sCOD & $\mathrm{mg} / \mathrm{L}$ & 5290.5 \\
nbsCOD & $\mathrm{mg} / \mathrm{L}$ & $3207 \cdot 3$ \\
nbpCOD & $\mathrm{mg} / \mathrm{L}$ & 4308.2 \\
TSS & $\mathrm{mg} / \mathrm{L}$ & 1825 \\
VSS & $\mathrm{mg} / \mathrm{L}$ & 1551.25 \\
VSSCOD & - & 2.274 \\
NOx & - & 0.221 \\
Taerasi & hours & 8 \\
Tsettle & hours & 2 \\
Tdecant & hours & 2 \\
Tidle & hours & 0 \\
Tfill & hours & 12 \\
Long & $\mathrm{m}$ & 0.75 \\
Wide & $\mathrm{m}$ & 0.6 \\
Depth & $\mathrm{m}$ & 1 \\
Large & $\mathrm{m}$ & 0.45 \\
Volume & $\mathrm{m}$ & 0.45 \\
\hline & &
\end{tabular}

The Operation and Maintenance (O\&M) cost of an SBR system is similar to that of a conventional activated sludge system. Typical costs associated with wastewater treatment systems include labour, overhead, supplies, maintenance, operations administration, utilities, chemicals, safety and training, laboratory testing, and solids handling.

Table 6. Calculation results of sbr design parameters

\begin{tabular}{lll}
\hline \multicolumn{1}{c}{ Parameters } & Unit & Value \\
\hline bCOD & $\mathrm{mg} / \mathrm{L}$ & 1302 \\
nbVSS & $\mathrm{mg} / \mathrm{L}$ & 1894.2 \\
iTSS & $\mathrm{mg} / \mathrm{L}$ & 273.75 \\
MLVSS & $\mathrm{mg} / \mathrm{L}$ & 681.298 \\
MLVSS/MLSS & & 0.209 \\
F/M & $\mathrm{kg} / \mathrm{kg} \cdot$ day & 0.623 \\
BOD Loading & $\mathrm{kg} / \mathrm{m}^{3}$ day & 0.422 \\
HRT & hours & 120 \\
SRT & hours & 1.749 \\
Number of Cycles & $/$ day & 1 \\
Volume fill & $\mathrm{m}^{3}$ & 0.089 \\
Tub Volume & $\mathrm{m}^{3}$ & 0.445 \\
Large area tub & $\mathrm{m}^{2}$ & 0.445 \\
Sludge Settling Chamber Volume & $\mathrm{m}^{3}$ & 0.0444 \\
\hline
\end{tabular}


Ozone can be produced using high-frequency, high-voltage power and series-connected switches or resonant circuits (Abkenar et al., 2019). Ozone generator used in this study with a 49-88 $\mathrm{mg} / \mathrm{L}$ concentration with an oxygen flow rate of $5 \mathrm{~L} / \mathrm{min}$. This means that the dose of ozone given is around $49-88 \mathrm{mg} / \mathrm{minute}$. This ozone dose is based on the literature that uses ozone doses above 40 $\mathrm{mg} / \mathrm{minute}$ for colour concentrations above 8oo PtCo (Suryawan et al., 2021) and considers the volume of water used.

Table 7. Ozone generator specifications

\begin{tabular}{lll}
\hline Specification & Unit & Value \\
\hline Oxygen flow rate & liter/min & 1 \\
Ozone concentration & $\mathrm{mg} / \mathrm{L}$ & $49 \sim 88$ \\
Ozone output & $\mathrm{G} / \mathrm{hours}$ & 15 \\
Power & $\mathrm{Kw}$ & $\leq 0.924$ \\
Current & $\mathrm{A}$ & 4.2 \\
Heavy & $\mathrm{kg}$ & 89 \\
Dimension & $\mathrm{mm}$ & $480 \times 600 \times 950$ \\
\hline
\end{tabular}

Constructed wetlands are units used to remove organic matter, suspended solids, pathogenic organisms, and nutrients such as ammonia and other forms of nitrogen and phosphorus. The application of phytoremediation based on constructed wetlands is recommended as a further treatment in textile wastewater before being discharged into water bodies due to the high nutrient content in textile wastewater (Apritama et al., 2020). The specifications and design criteria for the constructed wetland unit are shown in Table 8 and Table 9.

Table 8. Constructed wetland specifications

\begin{tabular}{ll}
\hline Components & Design Criteria \\
\hline Wetland base & Clay layer with permeability $\mathrm{K}=10-6 \mathrm{~cm} / \mathrm{s}$ \\
Material filter & Geomembrane layer \\
Plants that can be used & Fine gravel diameter $(12-20 \mathrm{~mm})$ \\
Depth of wastewater & Coarse gravel diameter $(20-40 \mathrm{~mm})$ \\
Depth of tub & Fragrant roots; \\
Freeboard & Cattail; \\
Side slope & Papyrus; \\
\hline
\end{tabular}

(PUPR, 2017)

The operation and maintenance of the Constructed Wetlands are planned as a long-term project. Unit maintenance and inspection are carried out at least two times a year for effective operations divided into five parts (Sudewo, 2016). The initial stage of planting and selecting vegetation is the most essential thing in planning constructed wetlands. This time the plan uses Typha angustifolia (Cattail) vegetation using sand media that has porosity. The selection of vegetation is recommended with lush characteristics to block sunlight from entering the water and causing uncontrolled algae growth. The distance between plants is about $50 \mathrm{~cm}$ between plants to maximize plant growth. The inlet flow of water needs to be adjusted to keep the water level stable. The water level should be in the range of $10-15 \mathrm{~cm}$ above the surface of the planting medium. This can affect the effectiveness and absorption capacity of the vegetation in the wetlands. Complete details of the constructed wetland unit calculation can be seen in Table 10 and Table 11.

Table 9. Constructed wetland design criteria 


\begin{tabular}{lll}
\hline Parameters & Unit & Value \\
\hline Detention time (to remove dissolved pollutants) & day & $5-14$ \\
Detention time (to remove suspended pollutants) & day & $0.5-3$ \\
Maximum BOD 5 load rate & $\mathrm{kg} /$ ha.day & $80-112$ \\
Hydraulic load rate & $\mathrm{m} /$ day & $0.01-0.05$ \\
Surface area required & $\mathrm{ha} / \mathrm{m}$. day & $0.002-0.014$ \\
Length: width ratio & - & $4: 1-6: 1$ \\
Water depth - average conditions & $\mathrm{m}$ & $0.1-0.5$ \\
Base slope ratio & - & $3: 1-10: 1$ \\
\hline
\end{tabular}

(PUPR, 2017)

Table 1o. Preliminary data of constructed wetland unit calculation

\begin{tabular}{lll}
\hline Parameters & Unit & Value \\
\hline Wetland unit depth $(\mathrm{y})$ & $\mathrm{m}$ & 0.5 \\
Medium porosity $(\varepsilon)$ & & 0.4 \\
Initial concentration $(\mathrm{Co})$ & $\mathrm{mg} / \mathrm{L}$ & 217 \\
Effluent concentration $(\mathrm{Ce})$ & $\mathrm{mg} / \mathrm{L}$ & 0.13 \\
The constant rate at reference temperature $(\mathrm{Kr})$ & & 1.104 \\
Water temperature $(\mathrm{Ta})$ & ${ }^{\circ} \mathrm{C}$ & 25 \\
Reference temperature $(\mathrm{Tr})$ & ${ }^{\circ} \mathrm{C}$ & 20 \\
Temperature coefficient for reference temperature & $/$ day & \\
rate constant $(\Theta \mathrm{r})$ & & 1.06 \\
\hline
\end{tabular}

Table 11. Constructed wetland unit calculation results

\begin{tabular}{lll}
\hline Parameters & Units & Value \\
\hline Constant velocity at temperature Ta & $/$ day & 1.48 \\
(Kt) & $\mathrm{m}^{2}$ & 2.24 \\
Unit surface area (ACW) & $\mathrm{m}^{2}$ & 2.5 \\
& - & $4: 1$ \\
Length and Width Ratio & $\mathrm{m}$ & 0.8 \\
Unit width (L) & $\mathrm{m}$ & 3.2 \\
Unit length (P) & $\mathrm{m}^{2}$ & 2.56 \\
Unit surface area (ACW) & day & 5.74 \\
HRT & m/day & 0.035 \\
\hline
\end{tabular}

Table 12. Dimensions of constructed wetland units

\begin{tabular}{lll}
\hline Parameters & Unit & Value \\
\hline Length & 3.2 & $\mathrm{~m}$ \\
Width & 0.8 & $\mathrm{~m}$ \\
Depth & 0.5 & $\mathrm{~m}$ \\
Spacious & 2.56 & $\mathrm{~m}^{2}$ \\
Volume & 1.28 & $\mathrm{~m}^{3}$ \\
\hline
\end{tabular}

The WWTP was built on land with a size of $30 \mathrm{x} 12$ meters. The WWTP area has a batik wastewater treatment unit, namely a sequenced batch reactor and a constructed wetland. Next to the unit is the control room where the ozone generator is located. The WWTP area is also equipped with a beautiful garden, fishpond, and parking for two-wheeled vehicles. The layout of the WWTP can be seen in Figure 2. 


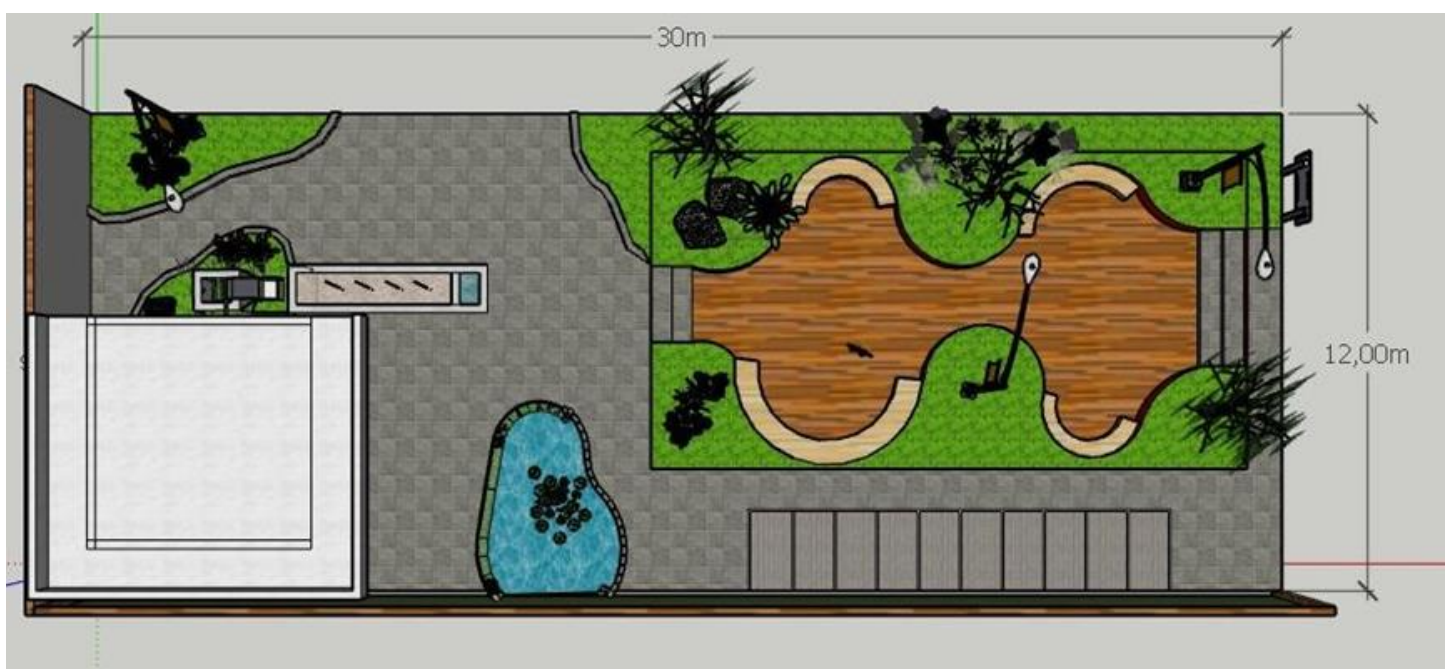

Figure 2. Layout of WWTP batik for small-scale business (usk) in Yogyakarta

In planning the USK Batik WWTP system this time, it was attempted not to use a pump by utilizing the elevation of a location with a height difference. This can be advantageous because there is no need for additional electricity costs, and the flow of water only depends on the force of gravity. The planning of this WWTP flow system is as shown in Figure 3. The planning of a wastewater treatment plant for batik medium-sized businesses in Yogyakarta is expected to become a pilot for several other batik production units. This plan includes a centralized processing technology for several batik centralizations in the city of Yogyakarta. This is a new design because in its application in the field, some only use biological treatment. The combination of pre-treatment and post-treatment is still said to be a new design breakthrough because it is only for some characteristics of the wastewater to be treated. Pre-treatment with ozone is used to break down long carbon chains so that they can be easily decomposed in biological processing, while post-treatment is used to degrade residual organic and inorganic compounds to produce better effluent quality.

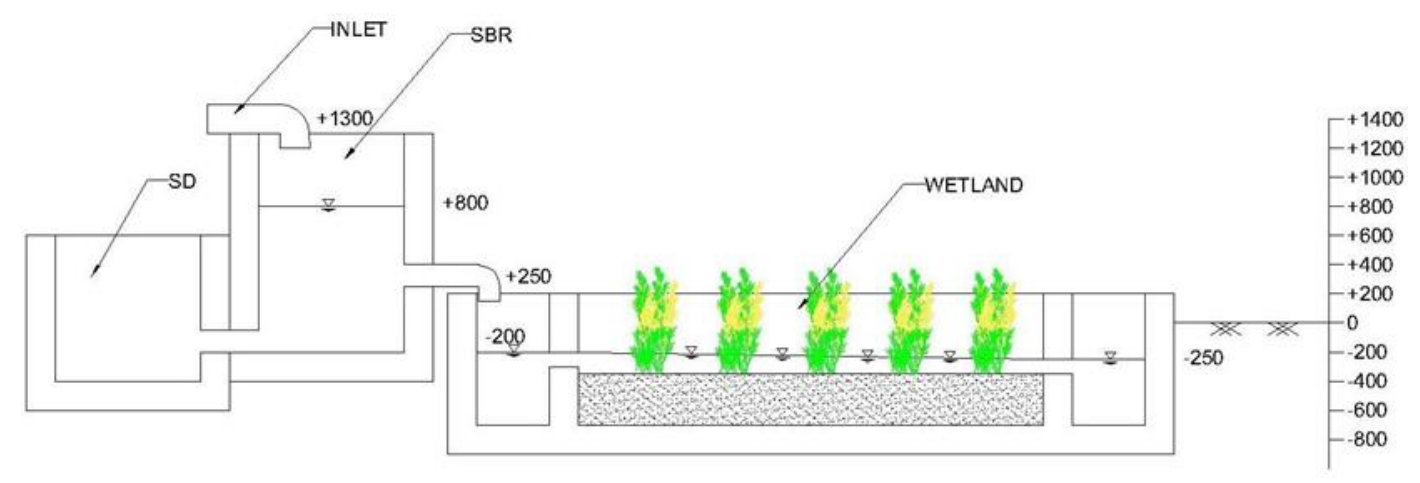

Figure 3. Hydraulic profile of WWTP batik for small scale business (USK) in Yogyakarta

\section{Conclusions}

Wastewater treatment plants for the industry are essential. This is because water use is extensive, and the batik industry's wastewater pollutants can pollute the environment, especially water bodies. This proposal carries two units for batik wastewater treatment at USK Batik X, Yogyakarta, namely the SBR and the constructed wetland. The batik industry's WWTP is small-scale and operated by the surrounding community. The concept of this WWTP is an environmentally friendly WWTP where there are gardens, mother-in-law's tongue plants, Angsana trees, and zodia plants that can eliminate odours and mosquitoes. The existence of a park can also eliminate the paradigm that WWTP is a slum 
and smelly place. Influent batik wastewater initially contained contaminants such as BOD, COD, and TSS, whose values were above the quality standard. After passing through the SBR unit and constructed wetland, the effluent was obtained, which met the quality standards and could be used for watering plants and fish ponds. The application of the $3 \mathrm{R}$ principle can be applied to the subsequent treatment, namely sludge treatment. The sludge produced in the batik waste treatment process can be used to manufacture Refuse-Derived Fuel (RDF). In addition, the oil collected from the oil removal process in batik wastewater treatment can be resold by used oil suppliers and manufacturers.

\section{References}

Abdulgani, H., Izzati, M., \& Sudarno. 2014. Kemampuan tumbuhan typha angustifolia dalam sistem subsurface flow constructed. BIOMA, 90-101.

Abkenar, P. P., Iman-Eini, H., Samimi, M. H., \& Bagheri, A. (2019, February). An ozone generator power supply for water purification. In 2019 1oth International Power Electronics, Drive Systems and Technologies Conference (PEDSTC) (pp. 383-388). IEEE.

Apritama, M., Suryawan, I., Afifah, A. S., \& Septiariva, I. Y. 2020. Phytoremediationof effluent textile wwtp for $\mathrm{NH}_{3}-\mathrm{N}$ and $\mathrm{Cu}$ reduction using pistia stratiotes. Plant Archives, 20(Supplement 1), 2384-2388.

Balai Besar Kerajinan dan Batik. 2010. Retrieved from kementerian perindustrian republik indonesia.

Cahyana, G. H., \& Aulia, A. N. 2019. Pengolahan air limbah rumah sakit menggunakan horizontal subsurface flow constructed wetland. EnviroSan: Vol. 2, Nomor 2, 58-64.

Dewanti, B. S., Prastiwi, T. F., \& Haji, A. T. 2019. Pengolahan limbah cair batik menggunakan kombinasi metode netralisasi dan elektrokoagulasi. Jurnal Rekayasa dan Manajemen Agroindustri, 358-369.

Djumanto, D., Probosunu, N., \& Ifriansyah, R. 2013. Indek biotik famili sebagai indikator kualitas air sungai gajahwong yogyakarta. Jurnal Perikanan Universitas Gadjah Mada, 15(1), 26-34.

Fadhilah, N., Vembrio, L. A. W., Safira, R. H., Amiruddin, A., Sofiyah, E. S., \& Suryawan, I. 2020. Modifikasi unit proses dalam peningkatan efisiensi penyisihan amonium. Jurnal Sumberdaya Alam dan Lingkungan, 7(2), 1-10.

Indrayani, L. 2018. pengolahan limbah cair industri batik sebagai salah satu percontohan ipal batik di yogyakarta. Ecotrophic, 173-184.

Indrayani, L., \& Triwiswara, M. 2018. Efektivitas pengolahan limbah cair industri batik dengan teknologi lahan basah buatan. Dinamika Kerajinan dan Batik, 53-66.

Khiatuddin, M. 2010. Melestarikan sumber daya air dengan teknologi rawa buatan. edisi kedua.yogyakarta: Gajah Mada University Press.

Marlina, N., Brontowiyono, W., \& Chasna, R. 2020. Analisis kualitas air dan daya tampung sungai dengan metode qual2kw (studi kasus: sungai code, yogyakarta). Jurnal Serambi Engineering, 5(4).

Metcalf, \& Eddy. 2014. Wastewater engineering: treatment and resource recovery. 5th Edition. New York: McGraw-Hill.

Mitchell, C., Wiese, R., \& Young, R. 1998. Design of wastewater wetlands in the constructed wetland manual Vol. 2. New South Wales, Australia: Department of Land and Water Conservation.

Sari, M. M., Hartini, S., \& Sudarno. 2015. Pemilihan desain instalasi pengelolaan air limbah batik yang efektif dan efisien dengan menggunakan metode life cycle cost. Jurnal Teknik Industri Universitas Diponegoro, 27-32.

Sastrawijaya, A. T. 1991. Pencemaran lingkungan. Surabaya: Penerbit Rineka Cipta.

Septiariva, I. Y., \& Sarwono, A. 2021. Reactive Black 5 (RB5): Pengolahan air limbah tekstil dengan adsorbsi menggunakan powdered karbon aktif. Jurnal Teknologi Lingkungan, 22(2), 199-205.

Sudewo, A. R. 2016. Hybrid constructed wetland (hcw) sebagai upaya pengolahan air limbah domestik pada pemukiman padat penduduk di daerah bantaran sungai (studi kasus: kejayan gebang kelurahan gebang putih surabaya). Surabaya: Institut Teknologi Sepuluh Nopember. 
Suryawan, I. W. K., Prajati, G., Afifah, A. S., \& Apritama, M. R. 2021. NH3-N and COD reduction in Endek (Balinese textile) wastewater by activated sludge under different DO condition with ozone pre-treatment. Walailak Journal of Science and Technology (WJST).

Suryawan, I., Siregar, M. J., Prajati, G., \& Afifah, A. S. 2019. Integrated ozone and anoxic-aerobic activated sludge reactor for endek (balinese textile) wastewater treatment. Journal of Ecological Engineering, 20(7).

Sutardi, A., Suprayogi, S., \& Adji, T. N. 2017. Kajian kualitas air tanah bebas antara sungai kuning dan sungai tepus di kecamatan ngemplak, yogyakarta, indonesia. Majalah Geografi Indonesia, 31(1), 31-38.

Taylor, G. 2011. Right sizing the design of ozone generator for multiple plant upgrades in orlando. Florida Water Resources Journal, 10-19. 